\title{
Trade Union Membership in the Coppermines of Zambia: A Test of Some Hypotheses
}

\section{Citation}

Bates, Robert H. 1972. Trade union membership in the coppermines of Zambia: a test of some hypotheses. Economic Development and Cultural Change 20, no. 2: 280-298.

\section{Published Version}

http://dx.doi.org/10.1086/450548

\section{Permanent link}

http://nrs.harvard.edu/urn-3:HUL.InstRepos:3710398

\section{Terms of Use}

This article was downloaded from Harvard University's DASH repository, and is made available under the terms and conditions applicable to Other Posted Material, as set forth at http:// nrs.harvard.edu/urn-3:HUL.InstRepos:dash.current.terms-of-use\#LAA

\section{Share Your Story}

The Harvard community has made this article openly available.

Please share how this access benefits you. Submit a story.

\section{Accessibility}




\title{
Trade Union Membership in the Coppermines of Zambia: A Test of Some Hypotheses*
}

\author{
Robert H. Bates \\ California Institute of Technology
}

\section{Introduction}

The study of voluntary associations is a principal concern of students of developing societies. Some analysts, following Wirth, view the emergence of associations as a major stage in the transition to the more complex and differentiated social structures that are characteristic of modern societies. ${ }^{2}$ Others see urban associations as the principal locus of acculturation into modern norms and practices. ${ }^{2}$ Still others stress the crucial role of associa-

* I wish to acknowledge the support I received from the Foreign Area Fellowship Program and the National Science Foundation (Doctoral dissertation research in political science, grant no. G.S. 1210), which made it possible to collect the data for this study. I wish also to acknowledge the support of the Center for International Studies of the Massachusetts Institute of Technology, which provided the funds for data analysis and published an earlier version of this paper.

${ }^{1}$ Louis Wirth, "Urbanism as a Way of Life," American Journal of Sociology 44 (July 1938): 1-25. As examples of contemporary writings, see Immanuel Wallerstein, "Ethnicity and National Integration," Cahiers d'études africaines 1 (1960): 129-39; and William B. Schwab, "Oshogbo--an Urban Community?" in Urbanization and Migration in West Africa, ed. Hilda Kuper (Berkeley and Los Angeles: University of California Press, 1965), pp. 85-109.

2 Thus, Banton states: "Some understanding of the emergence and spread of new norms may be gained from the study of new institutions. Voluntary associations are of particular interest in this respect, for the new norms are frequently rendered explicit in the association's constitution or activities, and are taught to novices as the distinguishing characteristic of the organization." This quotation appears in Michael F. Banton, A West African City: A Study of Tribal Life in Freetown (London: Oxford University Press, 1957), p. 5. See also Michael Banton, "Adaptation and Immigration in the Social System of Temne Immigrants in Freetown," in Social Change: The Colonial Situation, ed. Immanuel Wallerstein (New York: John Wiley \& Sons, 1966), pp. 402-19; Kenneth Little, "The Organization of Voluntary Associations in West Africa," Civilisations 9 (1959): 283-97; Kenneth Little, West African Urbanization: A Study of Voluntary Associations in Social Change (Cambridge: Cambridge University Press, 1965); Philip Mayer, Townsmen or Tribesmen (Capetown: Oxford University Press, 1961); and Philip Mayer, "Some Forms of Religious Organization among Africans in a South African City," in Urbanization in African Social Change: Proceedings of the Inaugural Seminar Held in the Centre of African Studies, University of Edinburgh, ed. Kenneth Little (Edinburgh: Centre of African Studies, 1963), pp. 113-26. 
tions in the development of modern party structures, capable of integrating and directing national political systems. ${ }^{3}$

Despite the emphasis on associations that characterizes so much of the literature on modernization, there have been few systematic, quantitative studies of the determinants of associational membership in the developing areas. This paper seeks to correct the oversight. First, taking advantage of the comparative method, we will relate our findings collected in the copper belt of Zambia to the results of other studies conducted in the United States. The contrast between the two suggests new hypotheses about patterns of joining in associations. Second, we will test propositions developed in the literature on African associations; in particular, we will explore the effects of ethnicity and urban stabilization as determinants of associational membership. We will then attempt to test two major, competing interpretations of the factors influencing membership in urban associations-interpretations which underlie many of the studies conducted in both the United States and Africa.

\section{The Mineworkers' Union of Zambia}

Our study focuses on the pattern of membership in the Mineworkers' Union of Zambia. ${ }^{4}$ The Mineworkers' Union is the largest union in Zambia and one of the biggest in all of Africa. The union was formed as the Northern Rhodesia African Mineworkers' Union in 1948. In 1955, the union temporarily split, with the mines' police and staff employees forming separate industrial organizations. At the same time the data were collected (January 1968), the staff and the mines' police had rejoined the Mineworkers' Union in response to the government's policy of "one union in one industry." The current membership of the union is over $20,000 .^{5}$

${ }^{3}$ See, for example, Thomas Hodgkin, Nationalism in Colonial Africa (New York: New York University Press, 1957); Immanuel Wallerstein, Africa, the Politics of Independence (New York: Vintage Books, 1961); and James S. Coleman, Nigeria: Background to Nationalism (Berkeley and Los Angeles: University of California Press, 1958). For examples of case studies of the contribution of voluntary associations to the formation of particular parties, see Frank G. Snyder, One-Party Government in Mali (New Haven, Conn.: Yale University Press, 1965); Aristide Zolberg, One-Party Government in the Itory Coast (Princeton, N.J.: Princeton University Press, 1965); and Dennis Austin, Politics in Ghana: 1946-1960 (London: Oxford University Press, 1964). From the point of view of the general literature on political development, participation in voluntary associations relates most directly to the concepts of "participant society," "social mobilization," and "social communications" (see Daniel Lerner, The Passing of Traditional Society, Modernizing the Middle East [New York: Free Press, 1958]; and Karl W. Deutsch, Nationalism and Social Communication [Cambridge, Mass.: M.I.T. Press, 1953]).

${ }^{4}$ Throughout this paper, subscription to the checkoff is used as the index of membership in the Mineworkers' Union.

${ }^{5}$ For further information on the Mineworkers' Union, see A. L. Epstein, Politics in an Urban African Community (Manchester: Manchester University Press, on behalf of the Rhodes-Livingstone Institute, Northern Rhodesia, 1958); also, Robert H. Bates, Unions, Parties, and Political Development: A Study of Mineworkers in Zambia (New Haven, Conn.: Yale University Press, 1971). See also the relevant sections of David C. Mulford, Zambia, the Politics of Independence 1957-1964 


\section{The Sample}

The data were gathered from a systematic, random, 20 percent sample of the male mine employees of Rhokana Corporation, one of the largest mines of the Zambian copper industry. Upon signing on with the mines, each worker receives a six-digit mine number. The digits 8 and 5 were selected from a table of random numbers and the records scanned for every miner whose number ended in either digit. Use of the last digit prevented sampling bias by time periods. Table 1 indicates the degree of fit of the sample with census data published by the mines themselves. The breakdown is by date engaged, staff and daily-rated workers, and the employees' provinces of origin. The sample fits the population sufficiently well to enable generalizations to the population with low levels of error (less than 2 percent) except in the case of small cell entries (less than thirty).

After collecting the data, a 10 percent random sample of the records was recoded and the results compared for coding errors. Only in the case of the occupation code did the level of error exceed 1 percent. Precise breakdowns by occupation are omitted from the following analysis (see table 1).

\section{Comparisons with United States Findings}

In analyzing the correlates of membership in the Mineworkers' Union, we concentrate on variables which have received attention in studies of associational and trade union membership in the United States. Such a selection enables cross-national tests of propositions about the determinants of participation in voluntary associations.

\section{A. Life-Cycle Variables}

Some of the most powerful correlates of associational membership in the United States are life-cycle variables: sex, age, and marital status. Because nearly all the mine workers are men (over 98 percent), the sample was selected from males only, and we therefore cannot test for sex-related differences in union membership.

\footnotetext{
(London: Oxford University Press, 1968); and Robert I. Rotberg, The Rise of Nationalism in Central Africa: The Making of Malawi and Zambia 1873-1964 (Cambridge, Mass.: Harvard University Press, 1965). From a more economic perspective, see Robert E. Baldwin, Economic Development and Export Growth: A Study of Northern Rhodesia, 1920-1960 (Berkeley and Los Angeles: University of California Press, 1966). The successful implementation of a policy of "one union in one industry" should not suggest a high level of governmental intervention in labor relations in the mines. The policy was largely implemented by the trade union leaders themselves, many of whom naturally were eager to reestablish unity in the organized labor force. More recently, the government of Zambia has nationalized the mines. In the future, therefore, there will be a much higher level of direct government involvement in labor relations. This major departure from a voluntaristic pattern of labor relations took place well after these data were collected, and therefore has no bearing on our findings.
} 
Robert H. Bates

TABLE 1

Degree of Fit of Sample with Census Data Published by the Mines

\begin{tabular}{|c|c|c|c|c|}
\hline \multirow{2}{*}{\multicolumn{2}{|c|}{ SAMPLE }} & \multirow[b]{2}{*}{$\underset{\text { EMPLOYEES }}{\text { AlL }}$} & \multicolumn{2}{|c|}{ DEGREE OF FIT * } \\
\hline & & & $\begin{array}{c}\text { For } \\
\text { Sample }\end{array}$ & $\begin{array}{c}\text { For All } \\
\text { Employees }\end{array}$ \\
\hline \multicolumn{5}{|c|}{ A. Staff Employees by Date Engaged } \\
\hline $\begin{array}{l}\text { Pre-1940. } \ldots \ldots \ldots \ldots \ldots \\
1941-45 \ldots \ldots \ldots \ldots \ldots \\
1946-50 \ldots \ldots \ldots \ldots \ldots \\
1951-55 \ldots \ldots \ldots \ldots \ldots \\
1956-60 \ldots \ldots \ldots \ldots \ldots \\
1961-65 \ldots \ldots \ldots \ldots \ldots \\
1966-68 \ldots \ldots \ldots \ldots \ldots\end{array}$ & $\begin{array}{l}13 \\
10 \\
37 \\
71 \\
88 \\
60\end{array}$ & $\begin{array}{r}17 \\
49 \\
69 \\
154 \\
367 \\
427 \\
300\end{array}$ & $\begin{array}{l}0.047 \\
0.037 \\
0.133 \\
0.256 \\
0.316 \\
0.216\end{array}$ & $\begin{array}{l}0.012 \\
0.035 \\
0.050 \\
0.111 \\
0.265 \\
0.307 \\
0.216\end{array}$ \\
\hline Total. . . . . . . . & 279 & 1,383 & 1.005 & 0.996 \\
\hline \multicolumn{5}{|c|}{ B. Daily-rated Employees by Date Engaged } \\
\hline $\begin{array}{l}\text { Pre-1940. } \ldots \ldots \ldots \ldots \ldots \\
1941-45 \ldots \ldots \ldots \ldots \\
1946-50 \ldots \ldots \ldots \ldots \\
1951-55 \ldots \ldots \ldots \ldots \\
1956-60 \ldots \ldots \ldots \ldots \ldots \\
1961-65 \ldots \ldots \ldots \ldots \ldots \\
1966-68 \ldots \ldots \ldots \ldots \ldots\end{array}$ & $\begin{array}{r}9 \\
44 \\
115 \\
251 \\
422 \\
802 \\
251\end{array}$ & $\begin{array}{r}55 \\
227 \\
584 \\
1,211 \\
2,100 \\
3,997 \\
1,192\end{array}$ & $\begin{array}{l}0.005 \\
0.023 \\
0.061 \\
0.133 \\
0.221 \\
0.425 \\
0.133\end{array}$ & $\begin{array}{l}0.006 \\
0.024 \\
0.062 \\
0.129 \\
0.224 \\
0.428 \\
0.128\end{array}$ \\
\hline Total............. & 1,894 & 9,366 & 1.001 & 1.001 \\
\hline \multicolumn{5}{|c|}{ C. All Employees by Province of Origin } \\
\hline 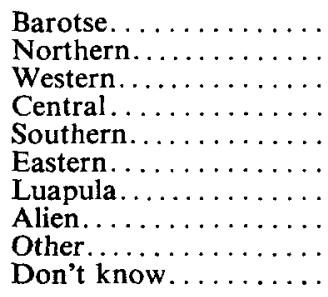 & $\begin{array}{r}316 \\
679 \\
197 \\
199 \\
84 \\
206 \\
235 \\
205 \\
34 \\
24\end{array}$ & $\begin{array}{r}1,640 \\
3,339 \\
900 \\
934 \\
390 \\
1,037 \\
1,129 \\
1,056 \\
169 \\
115\end{array}$ & $\begin{array}{l}0.145 \\
0.310 \\
0.091 \\
0.092 \\
0.039 \\
0.095 \\
0.108 \\
0.094 \\
0.016 \\
0.011\end{array}$ & $\begin{array}{l}0.153 \\
0.316 \\
0.084 \\
0.087 \\
0.037 \\
0.097 \\
0.105 \\
0.099 \\
0.016 \\
0.011\end{array}$ \\
\hline Total. . & 2,179 & 10,809 & 1.001 & 1.005 \\
\hline
\end{tabular}

* Ratio of cell entries to the total.

However, we do find that in the Mineworkers' Union, as in unions in the United States, membership is a function of age, and older persons join more frequently than do youths. ${ }^{6}$ Thus, the mean age in months of mem-

${ }^{6}$ Murray Hausknecht, The Joiners: A Sociological Description of Voluntary Association Membership in the United States (New York: Bedminster Press, 1962); and Charles R. Wright and Herbert H. Hyman, "Voluntary Association Membership of American Adults: Evidence from National Sample Surveys," American Sociological Review 23 (June 1958): 284-94. See also Arnold S. Tannenbaum and Robert L. Kahn, Participation in Union Locals (Evanston, Ill.: Row, Peterson \& Co., 1958), p. 116. The best summary of studies of the correlates of union participation is William Spinrad, "Correlates of Trade Union Participation: A Summary of the Literature," American Sociological Review 15 (April 1960): 237-47. 
bers is 443.67 , while the mean age of nonmembers is 403.19 . Uneven group totals prevent the use of analysis of variance. As table 2 shows, however, dichotomizing age yields a significant relationship with union membership.

TABLE 2

Comparison of Correlates of Mineworkers' Union with the U.S. Findings

\begin{tabular}{|c|c|c|c|c|c|c|}
\hline $\begin{array}{c}\text { Variable of } \\
\text { Union Membership }\end{array}$ & Members & $\begin{array}{l}\text { Non- } \\
\text { members }\end{array}$ & Total & $\chi^{2}$ & Significance & $\varphi$ \\
\hline \multicolumn{7}{|l|}{ Age: } \\
\hline $\begin{array}{l}\text { Low } \ldots \ldots \ldots \ldots \ldots \ldots \\
\text { High } \ldots \ldots \ldots \ldots \ldots\end{array}$ & $\begin{array}{l}394(45.4) \\
468(58.3)\end{array}$ & $\begin{array}{l}473(54.6) \\
335(41.7)\end{array}$ & $\left.\begin{array}{l}867 \\
803\end{array}\right\}$ & 27.0 & .000 & .126 \\
\hline \multicolumn{7}{|c|}{ Age controlled by length of service: } \\
\hline $\begin{array}{l}\text { Low length, low age... } \\
\text { Low length, high age. }\end{array}$ & $\begin{array}{l}258(38.7) \\
160(41.5)\end{array}$ & $\begin{array}{l}409(61.3) \\
226(58.5)\end{array}$ & $\left.\begin{array}{l}667 \\
386\end{array}\right\}$ & .672 & .4122 & $\ldots$ \\
\hline $\begin{array}{l}\text { High length, low age. } \\
\text { High length, high age. }\end{array}$ & $\begin{array}{l}136(68.0) \\
308(73.9)\end{array}$ & $\begin{array}{r}64(32.0) \\
109(26.1)\end{array}$ & $\left.\begin{array}{l}200 \\
417\end{array}\right\}$ & 2.02 & .1553 & $\ldots$ \\
\hline \multicolumn{7}{|l|}{ Marital status: } \\
\hline $\begin{array}{l}\text { Married............ } \\
\text { Nonmarried...... }\end{array}$ & $\begin{array}{r}839(64.9) \\
95(26.4)\end{array}$ & $\begin{array}{l}454(35.1) \\
265(73.6)\end{array}$ & $\left.\begin{array}{r}1,293 \\
360\end{array}\right\}$ & 168.0 & .0000 & .32 \\
\hline \multicolumn{7}{|l|}{ Place of occupation: } \\
\hline $\begin{array}{l}\text { Surface } \ldots . . . \ldots \ldots \ldots \\
\text { Underground......... }\end{array}$ & $\begin{array}{l}465(54.1) \\
468(57.9)\end{array}$ & $\begin{array}{l}395(45.9) \\
340(42.1)\end{array}$ & $\left.\begin{array}{l}860 \\
808\end{array}\right\}$ & 2.35 & .1251 & $\cdots$ \\
\hline \multicolumn{7}{|c|}{ Place of occupation, low service, age: } \\
\hline $\begin{array}{l}\text { Low service, surface. . } \\
\text { Low service, } \\
\text { underground }\end{array}$ & $143(34.1)$ & $276(65.9)$ & $419)$ & 6.28 & .0122 & .0851 \\
\hline $\begin{array}{l}\text { underground ......... } \\
\text { Low age, surface...... } \\
\text { Low age, underground. }\end{array}$ & $\begin{array}{l}187(42.7) \\
157(39.0) \\
237(51.1)\end{array}$ & $\begin{array}{l}246(61.0) \\
227(48.9)\end{array}$ & $\left.\begin{array}{l}438 \\
403 \\
464\end{array}\right\}$ & 12.3 & .0005 & .119 \\
\hline Type of occupation: & & & & & & \\
\hline $\begin{array}{l}\text { Staff. } \ldots \ldots \ldots \ldots \ldots \\
\text { Nonstaff } \ldots \ldots \ldots \ldots\end{array}$ & $\begin{array}{r}87(51.3) \\
833(60.0)\end{array}$ & $\begin{array}{r}71(48.7) \\
658(40.0)\end{array}$ & $\left.\begin{array}{r}158 \\
1,491\end{array}\right\}$ & 1.20 & .9128 & $\ldots$ \\
\hline \multicolumn{7}{|c|}{ Type of occupation, high service, income: } \\
\hline $\begin{array}{l}\text { High service, staff. . } \\
\text { High service, nonstaff. }\end{array}$ & $\begin{array}{r}63(63.4) \\
533(88.1)\end{array}$ & $\begin{array}{r}35(35.7) \\
171(11.9)\end{array}$ & $\left.\begin{array}{r}98 \\
664\end{array}\right\}$ & 5.30 & .0213 & .0815 \\
\hline $\begin{array}{l}\text { High income, staff..... } \\
\text { High income, nonstaff. }\end{array}$ & $\begin{array}{r}70(53.0) \\
446(68.1)\end{array}$ & $\begin{array}{r}55(47.0) \\
201(31.9)\end{array}$ & $\left.\begin{array}{l}132 \\
647\end{array}\right\}$ & 7.33 & .0068 & .0975 \\
\hline Education & & & & & & \\
\hline 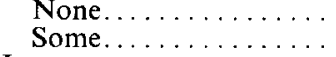 & $\begin{array}{l}378(56.0) \\
484(48.6)\end{array}$ & $\begin{array}{l}297(44.0) \\
511(51.4)\end{array}$ & $\left.\begin{array}{l}675 \\
995\end{array}\right\}$ & 12.2 & .0005 & .0835 \\
\hline \multicolumn{7}{|l|}{ Income: } \\
\hline $\begin{array}{l}\text { Low... } \\
\text { High . . }\end{array}$ & $\begin{array}{l}385(45.9) \\
526(66.9)\end{array}$ & $\begin{array}{l}453(54.1) \\
260(33.1)\end{array}$ & $\left.\begin{array}{l}838 \\
786\end{array}\right\}$ & 71.6 & .0000 & .21 \\
\hline
\end{tabular}

NoTE.- In this and later tables, the total is less than total sample size, as only Zambian citizens are used in the analysis. Percentages are shown in parentheses.

The relationship persists under successive controls for marital status, education, tribe, province of origin, and surface and underground employment. It fails to persist, however, when we control for length of service in the mines, as in table 2 . The data therefore suggest that age relates to membership because older persons have worked in the mining industry for longer periods of time. The relationship between length of employment and membership in associations exists in the United States as well, ${ }^{7}$ but

${ }^{7}$ Tannenbaum and Kahn, pp. 97-98; Leonard R. Sayles and George B. Strauss, The Local Union (New York: Harcourt, Brace \& World, 1967), p. 119; and Basil G. Zimmer, "Farm Background and Urban Participation," American Journal of Sociology 61 (March 1956): 470-75. 
has not been used to test the relationship between age and associational behavior.

In their analysis of United States data, Wright and Hyman determine that marrieds more frequently join associations than single persons; ${ }^{8}$ Dotson confirms and specifies the relationship ${ }^{9}$ and Tannenbaum extends the finding to trade unions. ${ }^{10}$ Our Zambian data corroborate this finding. Of all our variables, marital status has one of the strongest relationships with union membership (table 2); only length of service rivals or exceeds marital status in its strength of association. The relationship persists under all controls.

\section{B. Indicators of Class}

Of all the correlates of associational membership in the United States, class has perhaps received the most attention. Hausknecht, Lane, Wright and Hyman, Slater, and Scott-all report that the higher the class of a person, the greater his level of associational activity. ${ }^{11}$ Class also structures union participation, with "higher-class" workers revealing a greater propensity to form and join associations than those with "lower-class" backgrounds. ${ }^{12}$ The conventional indicators of class are occupation, education, and income.

As noted above, we are unable to use occupation as an independent variable. Not only are all the members of our sample of one occupation, strictly speaking, but also, our coding of jobs within the mine was too inaccurate to substantiate valid statistical inferences. We do have two indexes of occupational status, however: whether an employee works on the surface or underground and whether or not an employee holds a staff-grade job on the mines.

${ }^{8}$ See Wright and Hyman.

${ }^{9}$ Floyd Dotson, "Patterns of Voluntary Association among Working Class Families," American Sociological Review 16 (October 1951): 687-93.

${ }_{10}$ Arnold S. Tannenbaum, "Unions," in Handbook of Organizations, ed. James G. March (Chicago: Rand McNally \& Co., 1965), p. 747.

${ }^{11}$ Murray Hausknecht; Charles R. Wright and Herbert H. Hyman; John C. Scott, Jr., "Membership and Participation in Voluntary Associations," American Sociological Review 22 (June 1957): 321-26; Robert E. Lane, Political Life (New York: Free Press, 1962); Carol Slater, "Class Differences in Definition of Role and Membership in Voluntary Associations among Urban Married Women," American Journal of Sociology 65 (May 1960): 616-19.

${ }^{12}$ The history of union formation in the United States and elsewhere reveals that workers from skilled jobs, requiring greater training and education and yielding higher incomes, took the initiative in forming and joining trade unions. Moreover, unions drawing members from "higher-class" occupations tend to have higher levels of participation; see Seymour Martin Lipset, Martin Trow, and James S. Coleman, Union Democracy (Garden City, N.Y.: Doubleday \& Co., 1962). Last, it is generally found that within unions, workers with more highly skilled occupations, more education, and higher pay reveal higher levels of participation. See Tannenbaum and Kahn, pp. 96 and 116; and Spinrad. As teacher strikes and strikes by local government employees reveal, the troublesome deviant case of the apathetic white-collar workers is now falling into line with this dominant trend. 


\section{Economic Development and Cultural Change}

In the mining community, surface workers tend to have higher-status jobs. Many have white-collar jobs; with some exceptions, their jobs are cleaner and less dangerous than those underground; and their jobs less frequently involve arduous manual labor and more frequently involve "brain work," to use the local term. ${ }^{13}$ As noted by Epstein, underground workers tend to view the surface workers as greatly advantaged by the European-dominated, corporate hierarchy. ${ }^{14}$ Despite the higher status of surface occupations, however, table 2 reveals that there is no significant difference between the rate of union membership of surface and underground workers. Not only is there no relationship between this index of occupational status and union membership but also, when we introduce controls, the emergent relations run counter to the direction predicted on the basis of United States data. In the Mineworkers' Union of Zambia, occupational status associates with union membership among those with low lengths of service in the mines and among younger miners. In both cases, however, underground workers join the union more frequently than do surface employees (table 2).

The finding is corroborated by differences in the patterns of joining of staff and nonstaff employees. Staff employees hold jobs which involve supervisory responsibility, technical skill, or responsibility for funds or privileged information. They form the white-collar cadres of the mine employees: the laboratory technicians, clerical and medical staff, personnel officers, and local supervisors. As shown in table 2, despite the status distinction between the two categories of workers, the nonstaff employees have a higher rate of participation in the union than do the staff workers. The difference is not significant, however. Controlling for tribe, marital status, and education fails to produce significant differences in joining between the two categories of workers. When we control for income and length of service in table 2, significant differences do emerge, but the relationship runs counter to that expected from United States findings: highly paid and long-service nonstaff join the Union more frequently than do staff employees with similar pay rates and tenure in the mines.

Further contradicting United States findings is the inverse relationship between education and union membership, shown in table 2. Uneducated miners more frequently join the union than do those who have received some schooling. The introduction of controls suggests that educated persons less frequently join the union because they are unmarried, younger, and have worked in the mines for shorter periods of time. Nonetheless, under none of the controls does the relationship reverse its direction, and the contrast with United States findings is striking.

${ }^{13}$ See J. Clyde Mitchell and A. L. Epstein, "Occupational Prestige and Social Status among Urban Africans in Northern Rhodesia," Africa 29 (January 1959): 22-40; and R. E. Hicks, "Occupational Prestige and Its Factors: A Study of Zambian Railway Workers," African Social Research 1 (June 1966): 41-58.

${ }^{14}$ Epstein, Politics in an Urban African Community, pp. 127-47. 
The last indicator of class is income. In conformity with patterns in the United States, income is positively related to union membership, as indicated in table 2. However, the relationship "partials out" when length of service is controlled. Thus, higher income appears to result from increased length of service in the mines, thereby generating the original relationship.

\section{Discussion}

We must ask what accounts for differences in United States findings and our own results regarding class-related differences in associational behavior. In the case of three of the four indicators of class, our data directly contradict the results of United States studies, and in the case of the fourth, the original correlation appears to be spurious. The contradiction suggests that critical additional factors must be introduced in the study of associational membership.

One possible such factor is the operation of the association itself--a factor which has received surprisingly little attention in the literature on "joining." ${ }^{15}$ On the basis of my fieldwork in the mining communities in Zambia, I did not find it too surprising that "higher-class" persons had lower rates of participation in the Mineworkers' Union. The union seeks to advance the position of its lower-class members-those who form the great majority of its rank and file. Thus, the union formulates wage demands in terms of absolute instead of percentage increases. Absolute increases benefit poorer workers, while percentage increases yield greater benefits to miners with higher incomes. So, too, the union's tendency to defend its "worker" members against its "supervisor" members, and to formulate demands for schemes of African advancement that would benefit its lower-class members instead of its higher-class members who possess higher qualifications. The more educated, higher-status workers therefore feel isolated in the union and ignored by it. As a result, we can hypothesize, they tend less frequently to join. Our analysis therefore suggests that the nature of an organization-its operations, as they impinge on its potential membership-is a crucial determinant of the pattern of joining, and that other studies of voluntary associations should give greater emphasis to this factor.

There is a second possible explanation for the differences between our findings and those from studies in the United States. The high rate of participation of upper-class workers in the United States is often interpreted in terms of the "dual loyalty" hypothesis. Workers with greater skill and higher-status occupations, it is reported, reveal higher job satisfaction and greater loyalty to the companies; their positive orientation to their work life carries over to greater participation in the collective activities of their fellow workers. It is thus held that company and union

${ }^{15}$ An exception is Floyd Dotson, who distinguishes patterns of membership between informal and formal associations. 
loyalties reinforce each other, and union participation is therefore characteristic of upper-class workers. ${ }^{16}$ In the mines in Zambia, however, upperclass workers do not reveal dual loyalties. The mines are racially stratified, and to enter the upper levels of employment is to directly confront the racially discriminatory pattern of the corporate structure. ${ }^{17}$ It is also to cut oneself off from the mass of the African workers. Relatively dissatisfied with company policies on the one hand and isolated from their fellow Africans on the other, the upper-class workers thus do not share the characteristics which account for the higher levels of participation by their counterparts in American industries.

There is a third possible explanation for the differences between our findings and those from the United States--one which takes into account the different levels of social development in the two areas: that urban stabilization and class formation are separate phenomena, and that while in the United States the two exist together, in the copper belt urbanization is more significant than class formation at this stage in its social development. One of our life-cycle variables, marriage, is a common indicator of urban stability; ${ }^{18}$ so is length of service in the mines, when interpreted as an index of the length of time spent in urban areas. ${ }^{19}$ Persons who have wives in town and a long residence in the mining community can be presumed to be more highly urbanized than others. The tendency for class factors to partial out when the indicators or urbanization are controlled suggests the overriding significance at this time of the process of urban stabilization. The failure of United States studies to report similar relationships suggests that both class and urbanization factors are significant and operative in American urban society. A test of this "stages" hypothesis

${ }^{16}$ See Arthur S. Tannenbaum, "Unions," p. 747; and Lois R. Dean, "Social Integration, Attitudes, and Union Activity," Industrial Labor Relations Review 8 (October 1964): 48-58. For a skeptical commentary on the concept of loyalty, see Tannenbaum and Kahn, pp. 107-9.

${ }^{17}$ Thus, for example, at the time the data were collected, those Africans who occupied the highest-level job categories-categories in which European workers also held jobs--were paid at rates far below those of their European co-workers. Since I wrote this article, a single wage scale, applicable to both races, has been implemented on the mines.

${ }^{18}$ Married here means married and wife in town; the records note marital status for the purpose of providing company housing for married miners. See Bruce Kapferer, The Population of a Zambian Municipal Township: A Preliminary Report of a 1964 Social Survey of the Broken Hill Municipal Township, University of Zambia, Institute for Social Research, communication no. 1 (Lusaka: Institute for Social Research, 1966). As he states, "It is noticeable that the percentage of males to females from the Northern, Eastern, and North-Western Provinces is almost equal. This indicates that a high proportion of men from these provinces have their womenfolk in town, which suggests that there is a greater likelihood for people from these areas to live in town for an extended period of time or to make town their home" (p. 21).

${ }^{19}$ See Kapferer; also Godfrey Wilson, An Essay on the Economics of Detribalization in Northern Rhodesia (Lusaka: Rhodes-Livingstone Institute, 1941 and 1942), pts. 1 and 2; Merran McCulloch, $A$ Social Survey of the African Population of Livingstone (Lusaka: Rhodes-Livingstone Institute, 1956); and J. Clyde Mitchell, African Urbanization in Ndola and Luanshya (Lusaka: Rhodes-Livingstone Institute, 1954). 
would require us to establish that the two sets of factors do not in fact "partial out" in United States data. It would also require longitudinal studies from the copper belt and a demonstration from future data that class variables remain significant when measures or urbanization are controlled. ${ }^{20}$

A fourth possible explanation is that the differing results stem from inappropriate comparisons; that is, that they are an artifact of the methodology and not real findings. According to this position, the proper comparison would not be with United States's associations in general, nor with American unions in particular, but rather with unions formed in company towns. The literature on associational behavior in company towns fails to suggest, however, that our findings would be different were we to make this comparison. The literature suggests that insofar as company towns do produce characteristic patterns of associational behavior, they tend either to promote mass apathy (i.e., low rates of joining), or militant participation (i.e., extremely high rates of joining, coupled with a high propensity to strike). The literature attributes the first pattern to the workers' fear of coercion and the company's monopoly of force in the local community. It attributes the second to the workers' isolation and to the social reinforcement they receive from living within an economically and occupationally homogeneous community. In either case, the clear implication is that company towns produce collectively higher or lower rates of union participation; there is no suggestion that they produce differing rates of membership among different categories of the labor force. It is the last phenomenon that is of concern to us in this study. ${ }^{21}$

\section{Text of Hypotheses about Associational Membership in Africa}

In addition to choosing variables which corresponded to categories employed in United States studies, we also selected variables of interest to studies of social behavior in Africa. The copper belt of Zambia has a rich research tradition and has generated a variety of hypotheses about patterns of social participation. ${ }^{22}$ Our data allow us to test some of these hypotheses as well as propositions developed from studies elsewhere in Africa.

${ }^{20}$ For a commentary on the lag of class formation, see Michael Banton, "Social Alignment and Identity in a West African City," in Urbanization and Migration in West Africa (n. 1 above), pp. 85-109.

21 The classic study of this topic is Clark Kerr and Abraham Siegel, "The Interindustry Propensity to Strike-an International Comparison," in Industrial Conflict, ed. A. Kornhauser, R. Dubin, and A. Ross (New York: McGraw-Hill Book Co., 1954), pp. 189-212. Also see Lipset's discussion and interpretation of their findings in his Political Man (Garden City, N.Y.: Doubleday \& Co., 1960), pp. 375-76. Suggestive of the reinforcing effects on union participation of living among those with whom one works are the findings of Lois $\mathbf{R}$. Dean. For a report on the depressant effects of company towns on union activities, see U.S., Congress, Senate, Subcommittee on Labor-Management Relations of the Committee on Labor and Public Welfare, Hearings on Labor-Management Relations in the Southern Textile Manufacturing Industry, 81 st Cong., 2d sess., pt. 1, 21-24 August 1950; pt. 2, 7 December 1950.

${ }^{22}$ The best guide to the research conducted on the copper belt is the Institute for Social Research, University of Zambia, A Complete List of the Publications of the Former Rhodes-Livingstone Institute (Lusaka: Institute for Social Research, 1967). 


\section{A. Ethnicity}

Many scholars contend that Africa, par excellence, is the continent of ethnic behavior. As discussed by Wallerstein, the concept of ethnicity has two basic dimensions: tribal membership and region of origin. ${ }^{23}$ I recorded over 100 tribes in my sample plus immigrants from all the provinces of Zambia.

In the light of contemporary politics and social conflict in Zambia, I aggregated my sample into four groups: Bemba, other tribesmen, persons from the Northern Province, and persons from the other provinces of Zambia. ${ }^{24}$ Political controversy in Zambia focuses, to a high degree, on the supposed dominance of Bemba speakers and persons from the Northern Province. ${ }^{25}$ In the mine townships of Rhokana, there are occasional accusations that the Union is "Bemba serving" and dominated by a "Northern Province clique." Tests of the validity of such accusations are in themselves important. From the standpoint of social theory, they are crucial, for the accusations clash directly with one of the fundamental hypotheses about ethnic behavior in Africa: that in the field of white-black relations-such as labor relations--tribal differences are irrelevant as determinants of social behavior. ${ }^{26}$

Our data in table 3 reveal that tribal background, in terms of being a Bemba or not, makes no significant difference for patterns of union membership. Differences in the propensity to join the union are, again, accounted for in terms of income, marital status, age, and length of service. The sole point at which tribe does make a difference is when income is low; as table 3 shows, poor Bemba more frequently join the union than do low paid workers from other tribes.

Similarly for province of origin: the factor bears no relationship with union membership that could not be accounted for by chance alone (table 3). Controlling for other factors largely fails to evidence a significant relationship between provincial background and union membership. Only in one case-among those with some education - does provincial background make a difference, and then in a way that counters contemporary accusations. Table 3 indicates that the Northern Province workers who have some education less frequently join the union than do educated employees from other areas.

In the Rhokana mining community, therefore, ethnicity has little

${ }^{23}$ Wallerstein, "Ethnicity and National Integration."

${ }^{24}$ In conformity with Wallerstein's nation of "super-tribalism," I counted as Bemba the Ushi, Mambwe, Bisa, Bwila, Tabwa, Luapula Lunda, Kabende, and others who are regarded, and who have come to regard themselves, as Bemba in the copper belt.

${ }^{25}$ See Robert 1. Rotberg, "Tribalism and Politics in Zambia," Africa Report 12, no. 9 (December 1967): 29-35.

${ }^{26}$ See Epstein, Politics in an Urban African Community, pp. 127-47; and J. Clyde Mitchell, The Kalela Dance: Aspects of Social Relationships among Urban Africans (Lusaka: Rhodes-Livingstone Institute, 1956). 
TABLE 3

Comparison of Variables of Interest to Studies of Social Behavior in Africa

\begin{tabular}{|c|c|c|c|c|c|c|}
\hline $\begin{array}{c}\text { Variable of } \\
\text { Union Membership }\end{array}$ & Members & $\begin{array}{l}\text { Non- } \\
\text { members }\end{array}$ & Total & $\chi^{2}$ & Significance & $\varphi$ \\
\hline \multicolumn{7}{|l|}{ Tribe: } \\
\hline 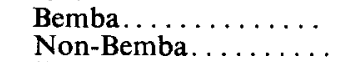 & $\begin{array}{l}598(57.2) \\
336(55.3)\end{array}$ & $\begin{array}{l}447(42.8) \\
272(44.7)\end{array}$ & $\left.\begin{array}{r}1,045 \\
608\end{array}\right\}$ & .525 & .4698 & $\cdots$ \\
\hline \multicolumn{7}{|l|}{ Tribe, low income: } \\
\hline $\begin{array}{l}\text { Bemba........... } \\
\text { Non-Bemba.... }\end{array}$ & $\begin{array}{r}287(49.5) \\
99(38.2)\end{array}$ & $\begin{array}{l}293(50.5) \\
160(61.8)\end{array}$ & $\left.\begin{array}{l}580 \\
259\end{array}\right\}$ & 8.69 & .0032 & .102 \\
\hline \multicolumn{7}{|l|}{ Province: } \\
\hline $\begin{array}{l}\text { Northern } . \ldots \ldots \ldots \ldots \\
\text { Other............. }\end{array}$ & $\begin{array}{l}392(54.0) \\
542(57.5)\end{array}$ & $\begin{array}{l}334(46.0) \\
401(42.5)\end{array}$ & $\left.\begin{array}{l}726 \\
943\end{array}\right\}$ & 1.88 & .1705 & $\cdots$ \\
\hline \multicolumn{7}{|c|}{ Province, some education: } \\
\hline $\begin{array}{l}\text { Northern........... } \\
\text { Other............ }\end{array}$ & $\begin{array}{l}154(42.9) \\
260(52.4)\end{array}$ & $\begin{array}{l}205(57.1) \\
236(47.6)\end{array}$ & $\left.\begin{array}{l}359 \\
497\end{array}\right\}$ & 7.18 & .0074 & .0915 \\
\hline \multicolumn{7}{|c|}{ Proportion of life in mines: } \\
\hline $\begin{array}{l}\text { Low. } \ldots \ldots \ldots \ldots \ldots \ldots \\
\text { High } \ldots \ldots \ldots \ldots \ldots\end{array}$ & $\begin{array}{l}328(38.8) \\
603(74.5)\end{array}$ & $\begin{array}{l}517(61.2) \\
206(25.5)\end{array}$ & $\left.\begin{array}{l}845 \\
809\end{array}\right\}$ & 2.13 & .0000 & .36 \\
\hline \multicolumn{7}{|c|}{ Tribe, controlled by marital status: } \\
\hline Married Bemba....... & $\begin{array}{l}539(66.1) \\
300(62.8)\end{array}$ & $\begin{array}{l}276(33.9) \\
178(37.2)\end{array}$ & $\left.\begin{array}{l}815 \\
478\end{array}\right\}$ & 1.36 & .2434 & .0315 \\
\hline $\begin{array}{l}\text { Not married Bemba... } \\
\text { Not married } \\
\text { Non-Bemba }\end{array}$ & $59(25.7)$ & $171(74.3)$ & 230 & .0884 & .7662 & .0141 \\
\hline \multicolumn{7}{|c|}{$\begin{array}{l}\text { Tribe, controlled by length of service } \\
\text { High service Bemba... } 397(76.4) \\
\text { High service }\end{array}$} \\
\hline 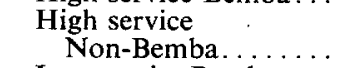 & $206(70.8)$ & 85( & 291) & 2.74 & .0981 & .058 \\
\hline $\begin{array}{l}\text { Low service Bemba.... } \\
\text { Low service }\end{array}$ & $200(37.8)$ & $329(62.2)$ & 529 & .213 & .6441 & .015 \\
\hline \multicolumn{7}{|c|}{$\begin{array}{l}\text { Tribe, controlled by proportion of life in mines: } \\
\text { High proportion }\end{array}$} \\
\hline $\begin{array}{l}\text { High proportion } \\
\text { Bemba........... }\end{array}$ & $405(76.4)$ & $125(23.6)$ & $530)$ & & & \\
\hline $\begin{array}{l}\text { High proportion } \\
\text { Non-Bemba... }\end{array}$ & & & & 2.58 & .1084 & .0565 \\
\hline Low proportion Bemba & $192(37.5)$ & $320(62.5)$ & 512 & & & \\
\hline $\begin{array}{l}\text { Low proportion } \\
\text { Non-Bemba }\end{array}$ & $136(40.8)$ & $197(59.2)$ & 333 & .813 & .3673 & .031 \\
\hline
\end{tabular}

effect upon patterns of membership in the Mineworkers' Union. Once again, we would hypothesize that it is the operation of the association that largely determines the influence of this factor upon patterns of joining. As discussed by Mitchell and Epstein, and as I myself observed, in white-black relations, African leaders generate social pressures to insure that ethnic cleavages are not allowed to emerge. Union leaders utilize social and economic sanctions to contain ethnic tensions and strive to preserve a solid labor, and solid black, front against the European management. This is not to say that ethnicity is not operative in the copper belt. As Mitchell and Epstein state, in inter-African relations, ethnic considerations govern many social patterns: hospitality, joking relationships, and domestic and kinship affairs, for example. But the structuring power of ethnicity is now allowed to carry over into the field of labor relations or to other activities involved in relationships between the white and black communities. 


\section{B. Urbanization as Detribalization}

If ethnicity is one of the key concepts in the sociology of modern Africa, urbanization is another. We have already tested one of the principal hypotheses about ethnicity. Our data enable a test of one of the central hypotheses about urbanization as well.

It is the contention of many that urbanization can best be conceived as the process of "detribalization." ${ }^{27}$ While we cannot test this hypothesis directly, we can test logical extensions of it. Marriage, length of residence in town, and the proportion of life spent in town can serve as indicators of urbanization. As we have already noted, being married in town and length of residence in urban areas (here analoged by length of employment in the mines) are common indicators of the extent of a person's commitment to urbanization. The proportion of life spent in town (here analoged by the proportion of life worked on the mines) has been suggested as a third such indicator. ${ }^{28}$

One of the logical extensions of the detribalization interpretation of urbanization is that the effects of tribal membership on social behavior weaken as the effects of urban, social factors increase. The data we have presented in part confirm this hypothesis. Ethnic factors, we have found, have little or no significance in determining associational membership. Much more significant are marital status and length of service with the mines; also significant (table 3 ) is the proportion of his life that a person has worked on the mines. The relationships persist under all controls.

Our data enable a more refined test of the hypothesis. If detribalization and urbanization are positively related, then the significance of tribal membership as a determinant of social behavior should be less among persons who, by our indexes, are more highly stabilized as urban residents. As table 3 reveals, however, the obtained relationships directly counter the predicted relations. The strength of the association between tribe and union membership increases among persons who are "high" on the indicators of commitment to urban life. In none of the cases are the

\footnotetext{
${ }^{27}$ See, for example, Godfrey Wilson; also E. Hellmann, Rooiyard: A Sociological Survey of an Urban Slum Yard (Lusaka: Rhodes-Livingstone Institute, 1948). For critiques of this approach, see J. Clyde Mitchell, "Urbanization, Detribalization, and Stabilization in Southern Africa: A Problem in Definition and Measurement," in UNESCO, Social Implications of Industrialization and Urbanization in Africa South of the Sahara (Paris: UNESCO, 1956). Perhaps the most radical and trenchant critique of this position is that of Max Gluckman in his article, "Tribalism in Modern British Central Africa," Cahiers d'études africaines 1 (January 1960): 55-70. Thus, Gluckman states, "The African is always tribalised, both in towns and rural areas; but he is tribalised in two quite different ways. . . Hence, the African in rural areas and in town is two different men; for the social situation of tribal home and of urban employment determines his actions and associations" (p. 69).

${ }^{28}$ See J. Clyde Mitchell, African Urbanization in Ndola and Luanshya. Our index differs from that of Mitchell in that ours is based upon the proportion of the worker's total life spent working in the mines while his is based upon the proportion of life spent in town since the age of fifteen.
} 
differences statistically significant, however, and we cannot reject the possibility that the relationships are produced by chance. ${ }^{29}$

\section{Urban Integration versus Urban Isolation as Determinants of Associational Membership}

There are two, basically contradictory, hypotheses about the determinants of associational membership. The first derives principally from the African literature and emphasizes that joining associations results from social isolation; the second stems mainly from the United States literature and finds that associational membership reaffirms social ties and is an expression of social integration.

Exemplifying the first position is the work of Banton, Little, and Fallers. ${ }^{30}$ All three cite the desire to reduce feelings of isolation and the need for intimacy, fellowship, and fraternity as primary motivations for joining associations; all three contend that participation in associations is characteristic of new immigrants into the urban areas. Proponents of the second position note that home owners more frequently join associations than do renters $;^{31}$ that persons with greater numbers of informal relationships in town have higher rates of associational memberships $;^{32}$ and that those who have "positive attitudes" toward their communities have higher rates of participation in associations. ${ }^{33}$ According to this position, associational membership, rather than reflecting social isolation, gives expression to existing ties with and commitments to urban society. The joining of associations is therefore said to be more characteristic of established residents in town than of new immigrants to urban areas. ${ }^{34}$

We can employ several of our variables to serve as measures of integration and isolation. Thus, we can identify those who are married, who are long-term employees of the mines, who have spent a high proportion of their lives in the mines, and who belong to the majority tribal grouping, as well as those who do not. Those who are married, we presume, are

${ }^{29}$ To be noted is that the direction of these relationships suggests that urbanization, as a force of modernization, increases the strength of ethnicity as a determinant of social behavior. Others have argued that this is indeed the case. Thus, see Weinstein's study of the Fang in Brian Weinstein, Gabon: Nation Building on the Ogooué (Cambridge, Mass.: M.I.T. Press, 1966); and the studies of "modern ethnicity" among the Bangala, Ibo, Kru, Mongo, and Baluba and Lulua reported in Charles W. Anderson, Fred R. van der Mehden, and Crawford Young, Issues of Political Development (Englewood Cliffs, N.J.: Prentice-Hall, Inc., 1967).

${ }^{30}$ Banton, A West African City, and "Adaptation and Immigration"; Little, West African Urbanization (n. 2 above); L. A. Fallers, "Introduction," in Immigrants and Associations, ed. L. A. Fallers (The Hague: Mouton \& Co., 1967), pp. 7-16.

${ }^{31}$ Hausknecht, Wright and Hyman, and Scott (n. 11 above).

${ }^{32}$ Morris Axelrod, "Urban Structure and Social Participation," American Sociological Review 21 (February 1956): 13-18.

${ }^{33}$ Howard E. Freeman, Edwin Novak, and Leo G. Reeder, "Correlates of Membership in Voluntary Associations," American Sociological Review 22, no. 5 (October 1957): 528-40. The concept of integration is also applied to union participation (see Dean, n. 16 above).

${ }^{34}$ Scott (n. 11 above) and Zimmer (n. 7 above). 
socially more integrated into the mine community, while single persons, we assume, are more isolated. Similarly, we assume that long-term employees and those who have spent a greater proportion of their lives working in the mines are more integrated into the mining community; employees who have just signed on, we can argue, occupy a social position analogous to immigrants and are socially more isolated. Finally, we assume that those who belong to the majority tribal group are socially more integrated into the mining community than those who do not.

Employing these indicators, we can test the competing interpretations of the determinants of associational membership. First, we can determine in which direction the relationships run: in the direction predicted by the integration theorists or in the direction predicted by those who stress social isolation as a determinant of associational membership. Second, we can construct two multivariate models and see which one best predicts the obtained relationships between the variables.

TABLE 4

Relationship BetWeen Two Theories of Associational Membership Determination

\begin{tabular}{|c|c|c|c|c|c|c|}
\hline $\begin{array}{c}\text { Variable of } \\
\text { Union Membership }\end{array}$ & Members & $\begin{array}{l}\text { Non- } \\
\text { members }\end{array}$ & Total & $x^{2}$ & Significance & $\varphi$ \\
\hline \multicolumn{7}{|l|}{ Tribe: } \\
\hline $\begin{array}{c}\text { Majority group } \\
\text { (Bemba) } \ldots\end{array}$ & $598(57.2)$ & $447(42.8)$ & $1,045)$ & \multirow[b]{2}{*}{.525} & \multirow[b]{2}{*}{.4689} & \multirow[b]{2}{*}{.. } \\
\hline $\begin{array}{l}\text { Minority group } \\
\text { (Non-Bemba). }\end{array}$ & $336(55.3)$ & $272(44.7)$ & 608 & & & \\
\hline Marital status: & & & & \multirow[b]{2}{*}{168} & \multirow[b]{2}{*}{.0000} & \multirow[b]{2}{*}{.32} \\
\hline 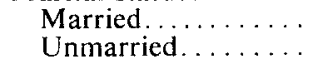 & $\begin{array}{r}839(64.9) \\
95(26.4)\end{array}$ & $\begin{array}{l}454(35.1) \\
265(73.6)\end{array}$ & $\left.\begin{array}{r}1,293 \\
360\end{array}\right\}$ & & & \\
\hline Proportion of life in mi & & & & \multirow[b]{2}{*}{213} & \multirow[b]{2}{*}{.0000} & \multirow[b]{2}{*}{.36} \\
\hline $\begin{array}{l}\text { High } \ldots \ldots \\
\text { Low. . . . . } \ldots \ldots\end{array}$ & $\begin{array}{l}603(74.5) \\
328(38.8)\end{array}$ & $\begin{array}{l}206(25.5) \\
517(61.2)\end{array}$ & $\left.\begin{array}{l}809 \\
845\end{array}\right\}$ & & & \\
\hline
\end{tabular}

As table 4 reveals, the direction of the relationships between our indicators and union membership favors the integration hypothesis, and in every case save one, the relationships are significant. All, save tribe, persist under all controls. The direction of the relationships therefore substantiates the integration theorists and calls into question the contention of those who view immigration and isolation as sources of associational membership. So, too, do the magnitude and significance of the relationships, save in the case of tribal membership.

The two theories can be modeled as shown in figure 1 . Thus, according to the integration theorists, married men more frequently join associations than unmarried, and it is highly probable that membership in the majority tribe increases the opportunities for marriage. Similarly, the higher the proportion of his life a worker spends in the mining community, the greater the likelihood that he will join the union. ${ }^{35}$ Conversely, the isolation

${ }^{35}$ Length of service is omitted in these representations as it is built into the index of proportion of life on the mines. Thus, the proportion index $=$ length of service $x$ 100/age. 


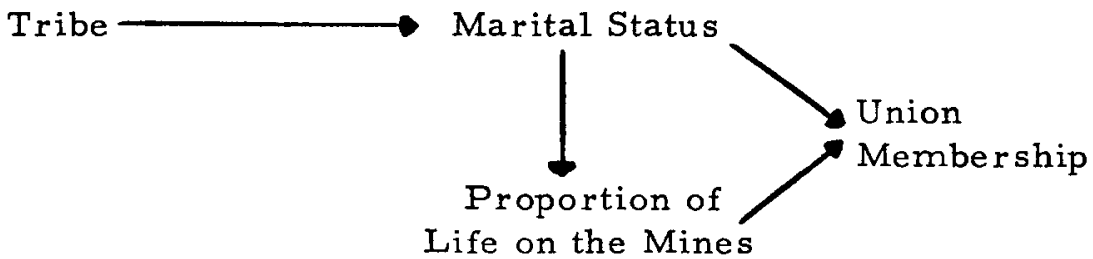

FIG. 1.-Model of two theories about the determinants of associational membership

theorists view the members of minority groups and new immigrants as more likely to join associations. The competing models are shown in figures 2 and 3 . The major predictions of the two models can easily be specified ${ }^{36}$ Thus, both predict that when marital status is controlled, there is no relationship between tribal group and union membership. They also predict that the relationship between the proportion of life which an employee has spent in the mine and union membership is not spurious, that is, does not result from their joint dependence on marital status. A test of the two predictions serves also to test the two models of associational membership.

In terms of the first prediction, as shown in table 5, there is little to choose between the two theories; both successfully predict the relationships between tribal membership, marital status, and associational membership. As revealed in table 6, however, the isolation theory fails to avoid a spurious relationship between failure to marry, a low proportion of life in mine employment, and membership in the union. The relationship between the proportion of life spent in mine employment and union

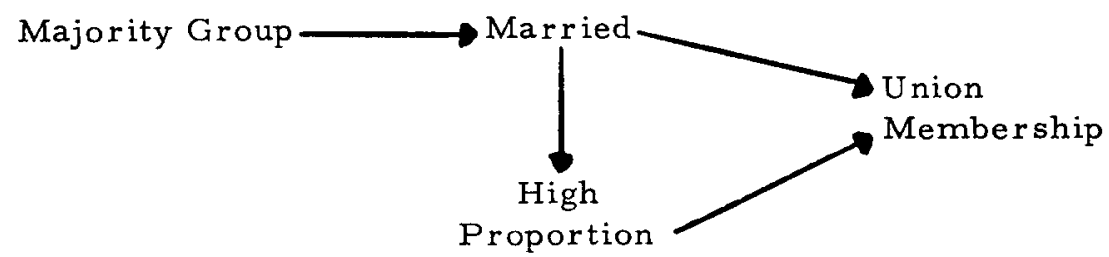

FIG. 2,- Model of integration theory

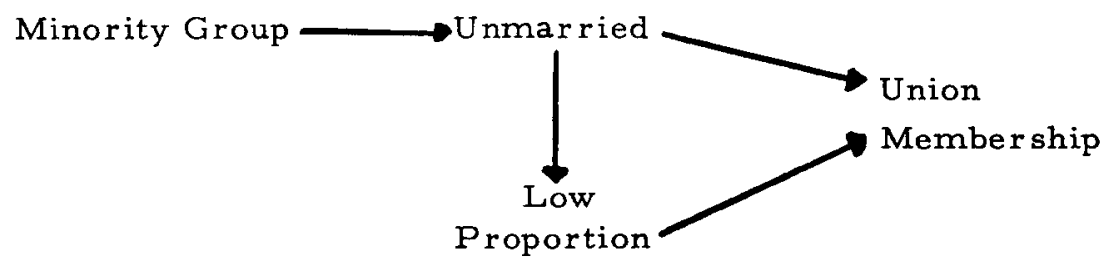

FIG. 3.-Model of isolation theory

${ }^{36}$ For an exposition of this technique, see George Wilbur, "Causal Models and Probability," Social Forces 46 (September 1967): 81-89. 
TABLE 5

Union Membership by Tribe, Controlled by Marital Status. Integration Theory Prediction

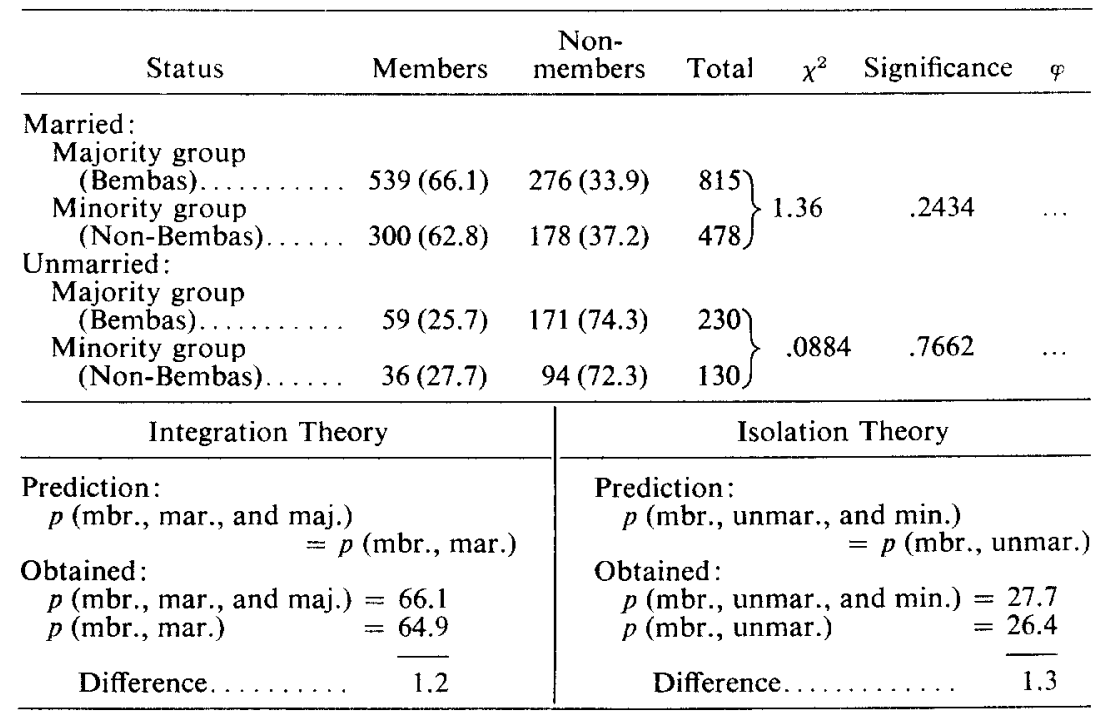

Note. $-p=$ probability $;$ mbr. = membership $;$ mar. $=$ married $;$ maj. $=$ majority group; unmar. = unmarried; min. = minority group.

TABLE 6

Union Membership by Marital Status, Controlled by Proportion of life in Mines. Isolation Theory Prediction

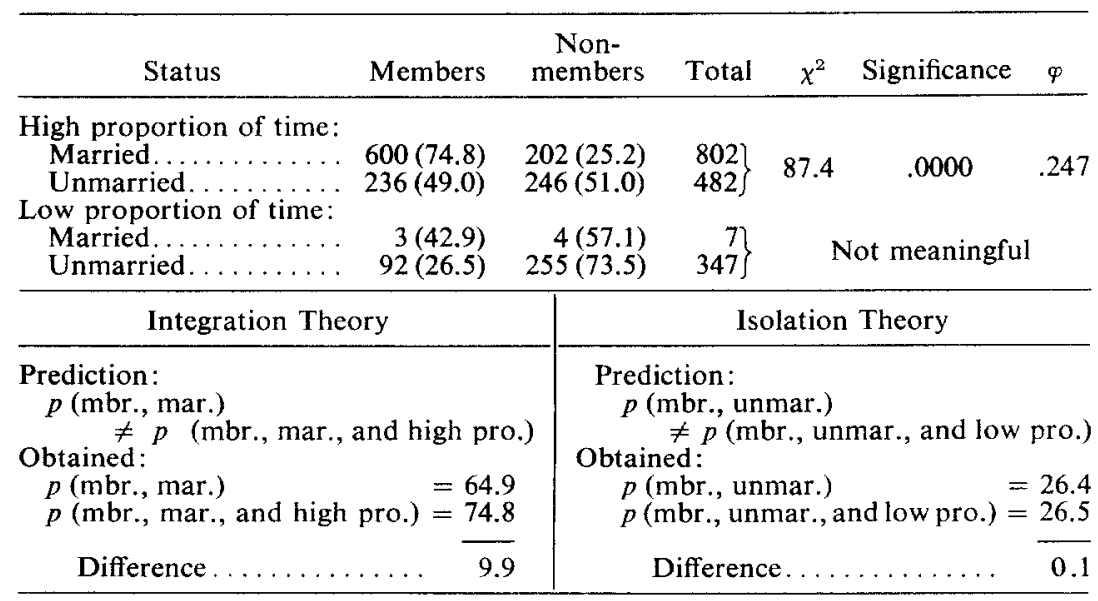

Note.-Abbreviations same as in table 6 , plus pro. = proportion. 
membership is nearly entirely accounted for by marital status alone. Thus, both in terms of the direction and magnitude of the relationships and in terms of their validity, the integration theory is substantiated and the isolation theory fails to find support from our data. Membership in this particular association reflects increased integration in the mining community rather than social isolation.

\section{Appendix}

As we have noted, one of the benefits of working on the copper belt is the existence of previous studies. We have two sets of early data on the Mineworkers' Union: a 1951 government study of Nchanga and Epstein's 1954 study of Roan. We also have Parkinson Mwewa's study of the Ndola branch of the Railway Workers' Union, conducted in 1957. It is interesting to note in brief the degree to which these studies support or contradict our findings.

\section{Life-Cycle Variables}

Unfortunately, only Mwewa's study contains breakdowns by age. His results confirm ours: older men, he finds, have higher rates of membership. Mwewa claims to detect no difference between the rates of membership of married and single men; his tabulations strongly suggest, however, that married men do possess significantly higher rates of joining than do men without wives. The Nchanga study also supports this position: whereas only 30 percent of the single miners had joined the union, slightly over 50 percent of the married workers were union members.

\section{Indicators of Class}

a) Occupational status. Epstein's data do not contain breakdowns by surface or underground workers; nor do they present separate figures for staff and daily-rated employees. The Nchanga study does present tabulations for surface and underground employees, and the data lend support to our position: while 42 percent of the underground workers contributed to the union checkoff, only 40 percent of the surface employees did so.

b) Education. Mwewa concludes that education is not "significant in determining union membership." 37 The Nchanga study fails to report findings for this factor. ${ }^{38}$ Epstein, in his study of Roan, argues that the proportion of educateds who are and are not members of the union is the same, that is, that there is no relationship between education and union membership. However, he lacks the data to substantiate his contention.

c) Income. Mwewa finds that those with higher income have higher rates of membership, but argues that this results from longer lengths of service. His position is therefore essentially the same as our own. Both the Roan and Nchanga studies report that the higher the worker's pay group, the greater the

37 Parkinson B. Mwewa, The African Railway Workers' Union, Ndola, Northern Rhodesia, Rhodes-Livingstone communication no. 10 (Rhodes-Livingstone Institute, 1958), p. 9.

${ }^{38}$ Northern Rhodesia Department of Labour, "Report on Membership in the Northern Rhodesia African Mine Workers' Union, Nchanga, April 1951," from the files of the Assistant Secretary of Labour, Lusaka. 
probability of membership; neither, however, introduces controls to test for spurious relationships.

d) Discussion. Thus, in some cases, there is a poor match between our data and the data from previous studies. However, where there are comparable observations, the findings from these studies tend to substantiate our results; and where they fail to do so, it is possible that had controls been introduced, they would have confirmed our findings. As to our interpretations, it is notable that Epstein comments: "Although only 18 percent of those in Groups 1-3 [the lowest pay groups] are paid-up members of the Union, together they account for 60 percent of the total membership. It is the workers in these groups, therefore, upon whom the Union primarily relies for financial support, to whom it addresses its appeals for cooperation, and for whom it claims to fight. ${ }^{"} 39$ Given the small number of advanced African workers on the railways ("a sprinkling of semiskilled and skilled workers" ${ }^{40}$ ), it is possible to interpret Mwewa's findings in the same manner. Higher-level Zambian workers may fail to join the unions in the same manner as comparable workers in the United States because the Zambian unions concentrate their efforts at the mass of the lower-class members.

\section{Other Variables}

The earlier studies present data on two other variables which we have measured: length of service and tribe.

a) Length of service. All three studies report that the longer the length of service, the higher the rate of union membership.

b) Tribe. Epstein's data reveal little difference in the rates of membership of different tribes, save for tribes from Nyasaland and the Central Province. He contends that these differences are spurious, being the result of differences in income and education; he lacks the data to confirm this contention, however. It is notable that when Epstein's data are aggregates into Bemba and Non-Bemba categories, as has been done in our study, then no significant differences emerge in the rates of membership between the two tribal groupings. The Nchanga study reports rates of membership for twentyfive tribes; again, aggregating the data in the same manner as we aggregated our own reveals no significant differences in tribal rates of union membership. This study also fails to introduce controls to test for spurious causes for intertribal differences in membership. In the case of Mwewa's data, the sample size is too small to test for significant differences in tribal rates of membership; at no point in his study does he suggest that tribe is a significant factor in rates of affiliation with the union or in other aspects of social and economic behavior.

${ }^{39}$ Epstein, Politics in an Urban African Community, p. 119.

${ }^{40}$ Mwewa, p. 3. 